\author{
KAMIL ANTONÓW \\ ORCID: 0000-0001-5669-0272 \\ Uniwersytet Opolski
}

\title{
KONCEPCJA RYZYKA SOCJALNEGO W POLSKIM PRAWIE UBEZPIECZEŃ SPOŁECZNYCH*
}

\begin{abstract}
Abstrakt: Zarys koncepcji ryzyka socjalnego w polskim prawie ubezpieczeń społecznych stworzono przy wykorzystaniu amerykańskiego (ekonomicznego) podejścia do teorii ryzyka ubezpieczeniowego ujmującego to pojęcie w kategoriach niebezpieczeństwa postrzeganego jako przyczyna realnych zdarzeń. W konsekwencji istota ochrony ubezpieczeniowej sprowadza się do odczuwania komfortu psychicznego (poczucia bezpieczeństwa materialnego) zapewnionego przez sam fakt ubezpieczenia. Tym samym za świadczenie wzajemne z tytułu bezwarunkowo opłacanej składki uważa się przejęcie i ponoszenie ryzyka przez ubezpieczyciela, a nie ewentualne wypłacenie świadczenia ubezpieczeniowego. Mając to na uwadze, ryzyko socjalne należy rozpatrywać nie od strony zaspokojenia potrzeb, jakie ono niesie, gdy się ziści (teoria świadczenia pieniężnego), lecz w kontekście świadczenia ubezpieczeniowej gwarancji „na wypadek” zajścia określonych zdarzeń (teoria ponoszenia ryzyka).
\end{abstract}

Słowa kluczowe: ryzyko socjalne, ryzyko ubezpieczeniowe, zdarzenie ubezpieczeniowe, ochrona ubezpieczeniowa, prawo ubezpieczeń społecznych

\section{TEORIE RYZYKA UBEZPIECZENIOWEGO}

W teorii ryzyka ubezpieczeniowego nie ma jednorodnego stanowiska co do istoty tego pojęcia. Szczególne zainteresowanie tym zagadnieniem wykazuje doktryna amerykańska, a za początek rozważań na ten temat uważa się pracę A.H. Willetta The Economic Theory of Risk and Insurance ${ }^{1}$ prezentującą ekonomiczną analizę ryzyka rozumianego jako niepewność. Negując przypadkowość procesów świata zewnętrznego ${ }^{2}$, autor definiował ryzyko w odniesieniu do stopnia

* Artykuł jest pełną wersją referatu wygłoszonego na międzynarodowej konferencji naukowej pt. The role of social risk as the premises for shaping social benefits systems (including legal, economic and social challenges in the modern state), Wrocław, 7 czerwca 2019 roku.

${ }^{1}$ A.H. Willett, The Economic Theory of Risk and Insurance, New York 1901.

2 Opierając się zatem na założeniach determinizmu filozoficznego wykluczającego przypadek jako zjawisko obiektywne, chyba że — jak twierdził (ibidem, s. 26) — przez przypadek rozumie się stopień prawdopodobieństwa, że dane zdarzenie nastąpi, ponieważ jest ono szacowane za pomocą 
niepewności co do wystąpienia straty, a nie w odniesieniu do stopnia prawdopodobieństwa jej wystąpienia; w tym sensie ryzyko określał więc jako obiektywną korelację subiektywnej niepewności ${ }^{3}$. Dwadzieścia lat później F.H. Knight wprowadził podział na niepewność mierzalną (measurable uncertainty) i niepewność niemierzalną (unmeasurable uncertainty), używając terminu „ryzyko” na określenie niepewności mierzalnej ${ }^{4}$, „prawdziwą” niepewność (a nie ryzyko) ograniczając do przypadków nieilościowych ${ }^{5}$. Do tak zarysowanego spojrzenia na relację ryzyka do niepewności nawiązał E.J. Vaughan, który wyraził pogląd, że niepewność jest po prostu reakcją psychologiczną na niewiedzę na temat przyszłości, natomiast z ryzykiem mamy do czynienia, gdy istnieje możliwość poniesienia straty, choćby jednostka narażona na ryzyko nie była go świadoma ${ }^{6}$. Innymi słowy należy dokonać rozróżnienia pomiędzy ryzykiem obiektywnym a subiektywnym $(\text { niepewnością })^{7}$, co jest istotne z punktu widzenia decyzji podejmowanych przez ludzi, którzy powinni działać na podstawie ryzyka rzeczywistego (obiektywnego), gdyż lepsza informacja zmniejsza niepewność (poprawia subiektywne oszacowanie ryzyka) i prowadzi do lepszych decyzji ${ }^{8}$. Z kolei I. Pfeffer stwierdził, że ryzyko jest kombinacją hazardu i jest mierzalne prawdopodobieństwem, niepewność zaś jest mierzalna stopniem wiary; ryzyko jest więc stanem świata realnego, niepewność - stanem umysłu9. Ostatecznie trudno jednoznacznie określić charakter związku ryzyka z niepewnością i uzgodnić jednolitą definicję ryzyka ubezpieczeniowego pojmowanego nie tylko w kontekście niepewności, lecz uznawanego także za: 1. szansę nastąpienia straty, 2. możliwość nastąpienia straty, 3. dyspersję

całej dostępnej wiedzy na temat warunków poprzedzających („By chance in that sense is meant the degree of probability that a particular event will occur, as it is estimated with the aid of all the attainable knowledge of the preceding conditions").

3 ,to define risk with reference to the degree of uncertainty about the occurrence of a loss, and not with reference to the degree of probability that it will occur. Risk in this sense is the objective correlative of the subjective uncertainty" - ibidem, s. 29.

${ }^{4}$ F.H. Knight, Risk, Uncertainty And Profit, Boston-New York 1921, s. 233.

5 „We shall accordingly restrict the term »uncertainty « to cases of the non-quantitive type. It is this »true « uncertainty, and not risk" - ibidem, s. 20.

${ }^{6}$ E.J. Vaughan, T. Vaughan, Fundamentals of Risk and Insurance, New York 2008, s. 3: „Uncertainty, then, is simply a psychological reaction to the absence of knowledge about the future. [...] When there is a possibility of loss, risk exists whether or not the person exposed to loss is aware of the risk".

${ }^{7}$ Taka niepewność (sensu stricto) bliska jest niepewności niemierzalnej w koncepcji F.H. Knighta.

8 ,The distinction between objective risk and subjective risk (i.e., between risk and uncertainty) is important because subjective risk affects the decisions people make. Ideally, they should make decisions based on actual risk (i.e., objective risk). Better information reduces uncertainty (improves subjective risk estimates) and leads to better decisions." - E.J. Vaughan, T. Vaughan, op. cit., s. 3; przyp. 4.

9 Zob. E. Kowalewski, Umowa ubezpieczenia na rzecz osoby trzeciej, [w:] Ubezpieczenia w gospodarce rynkowej, cz. 2, red. A. Wąsiewicz, Bydgoszcz 1994, s. 20 (za: I. Pfeffer, Insurance and Economic Theory, Homewood 1956, s. 42). 
rezultatów rzeczywistych i oczekiwanych, 4. prawdopodobieństwo wyniku innego niż oczekiwany, 5. niebezpieczeństwo i 6. przedmiot ubezpieczenia ${ }^{10}$.

Niezależnie od tych kontrowersji ogólnie można przyjąć, że ryzyko wiąże się z nieokreślonością i stratą, co otwiera drogę do zdefiniowania ryzyka jako stanu świata rzeczywistego, w którym występuje narażenie na niepomyślność; inaczej mówiąc - stanu, w którym istnieje możliwość niekorzystnego odchylenia od pożądanego rezultatu, który jest przewidywany lub oczekiwany ${ }^{11}$. Z zakresu tak rozumianego terminu „ryzyko" wyeliminować należy zatem taki rodzaj niepewności, która nie jest wymierna (policzalna aktuarialnie) i niekorzystna (nie przynosi straty). Dlatego też do ubezpieczenia nadają się tylko te ryzyka, które mają co najmniej charakter obiektywny (są naturalną konsekwencją określonych stanów przyrody, fizjologii człowieka czy zjawisk społeczno-ekonomicznych), probabilistyczny (w kategoriach a priori probability lub statistical probability) ${ }^{12}$ i czysty $\left(\right.$ pure risk) ${ }^{13}$.

Mając to na uwadze, należy stwierdzić, że zarysowane ekonomiczne podejście do ryzyka ma ograniczoną przydatność dla teorii ubezpieczeń. Słusznie bowiem zwraca się uwagę, że ekonomiczne pojęcie ryzyka koncentruje się na uszczerbkach w dobrach majątkowych (pomijając straty w dobrach osobistych) oraz wiąże ochronę z różnymi, trudnymi do określenia, czynnikami gospodarczymi, podczas gdy w ubezpieczeniu chodzi o ściśle wyselekcjonowane wypadki ubezpieczeniowe ${ }^{14}$. Ta słuszna konstatacja doprowadziła przed laty W. Warkałłe do sformułowania wniosku, że „punktem wyjścia dla badań teoretyczno-ubezpieczeniowych powinno być nie samo pojęcie ryzyka, jako prawdopodobieństwa nastąpienia określonych zdarzeń. Punktem wyjścia powinny być właśnie te zdarzenia i ich skutki społeczno-gospodarcze" ${ }^{15}$. W ten sposób w polskim prawie

10 Zob. E. Kowalewski, op. cit., s. 15-21; T. Michalski, [w:] Podstawy ubezpieczeń. Mechanizmy i funkcje, t. 1, red. J. Monkiewicz, Warszawa 2000, s. 24-31, którzy prezentując definicje ryzyka ubezpieczeniowego, nawiązują do definicji przedstawionych przez E.J. Vaughana i T. Vaughana - eidem, op. cit., s. 2; przyp. 1: „The term risk is variously defined as (1) the chance of loss, (2) the possibility of loss, (3) uncertainty, (4) the dispersion of actual from expected results, or (5) the probability of any outcome different from the one expected)".

11 ,We define risk as a condition of the real world in which there is an exposure to adversity. [...] Risk is a condition in which there is a possibility of an adverse deviation from a desired outcome that is expected or hoped for." - E.J. Vaughan, T. Vaughan, op. cit., s. 2-3.

$12 \mathrm{~W}$ odróżnieniu od ryzyk estymatycznych (estimates) ryzyka probabilistyczne mogą być obliczone albo metodami matematycznymi albo statystycznymi - podział wprowadzony przez F.H. Knighta - idem, op. cit., s. 224-225.

13 W odróżnieniu od ryzyk spekulatywnych (speculative risks) zajście ryzyka czystego przynosi stratę, niewystąpienie zaś ryzyka nie przynosi korzyści majątkowych — podział wprowadzony przez A.H. Mowbraya — zob. E. Kowalewski, [w:] Ubezpieczenia gospodarcze, red. T. Sangowski, Warszawa 2000, s. 34-35, za: A.H. Mowbray, R.H. Blanchard, Insurance: Its Theory and Practice in the United States, New York 1961, s. 6-7.

14 W. Warkałło, [w:] Ubezpieczenia majattkowe. Ochrona ubezpieczeniowa mienia społecznego, red. W. Warkałło, Warszawa 1971, s. 37.

15 Ibidem, s. 38. 
ubezpieczeniowym narodziła się koncepcja zdarzeń (wypadków) losowych, których występowanie warunkuje istnienie ryzyka ${ }^{16}$. Teoria zdarzeń losowych przeniknęła do doktryny prawa ubezpieczeń społecznych, w której również formułuje się poglądy, że zdarzenie (ryzyko) ubezpieczeniowe to sytuacja życiowa spowodowana zdarzeniem losowym ${ }^{17}$. Punkt ciężkości w pojmowaniu ryzyka ubezpieczeniowego przesunięty został tu $\mathrm{z}$ - właściwego podejściu ekonomicznemu zajmowania się przyczynami realnych zdarzeń na rezultaty, jakie one wywierają w sferze majątkowej, z zastrzeżeniem, że stworzenie kompleksowej teorii ryzyka wymaga wykorzystania obu konstrukcji intelektualnych ${ }^{18}$.

W dużym stopniu można więc stwierdzić, że koncepcja zdarzeń losowych — eksponując następstwa, jakie one wywołują w sferze zdolności do zdobywania środków utrzymania - jest teorią zaspokajania potrzeb materialnych wywołanych niepomyślnymi odstępstwami od normalnego (to jest nieprzynoszącego straty) obrotu ludzkich spraw; tym samym kładzie ona nacisk na zaspokojenie potrzeb za pomocą wypłaty świadczeń ${ }^{19}$. Natomiast istotą koncepcji ryzyka — ujmując go od strony niebezpieczeństw — jest ubezpieczenie „na wypadek” zajścia określonych zdarzeń, na dalszym planie upatrując świadczenia (kompensację skutków ryzyka), co pozwala lepiej zrozumieć sens gwarancyjnej funkcji ubezpieczenia oraz dostosować ochronę prawną do możliwości, celowości i kosztu zabezpieczenia potrzeb istniejących pierwotnie, to znaczy jeszcze przed wystąpieniem zdarzenia losowego ${ }^{20}$.

16 Ibidem, s. 38-40, 49 n.

17 Zob. W. Szubert, Ubezpieczenie społeczne. Zarys systemu, Warszawa 1987, s. 87 n.; I. Jędrasik-Jankowska, Pojęcia i konstrukcje prawne ubezpieczenia społecznego, Warszawa 2018, s. 129; A. Wypych-Żywicka, Renta rodzinna z Funduszu Ubezpieczeń Społecznych. Zagadnienia materialnoprawne, Gdańsk 2006, s. 34. Inaczej T. Zieliński, Ubezpieczenia społeczne pracowników. Zarys systemu prawnego - część ogólna, Warszawa-Kraków 1994, s. 180-181. Kwestionując rozróżnienie między zdarzeniami losowymi jako kategorią pozaprawną (faktyczną) a ryzykami ubezpieczeniowymi uznawanymi za zdarzenia ubezpieczeniowe, twierdził, że „Pomylenia ryzyk ze zdarzeniami ubezpieczeniowymi można uniknąć, przyjmując definicję ryzyka jako możliwości (niebezpieczeństwa) powstania zdarzenia losowego" (s. 181).

18 Zob. E. Kowalewski, [w:] Ubezpieczenia w gospodarce..., s. 11; T. Michalski, op. cit., s. $17-19$.

19 Zob. J. Łazowski, Wstęp do nauki o ubezpieczeniach, Warszawa 1934, s. 3, 6 n.; W. Szubert, op. cit., s. 48, 66; I. Jędrasik-Jankowska, op. cit., s. 129; D. Dzienisiuk, Prawo pracy a prawo ubezpieczeń spolecznych, Warszawa 2016, s. $57 \mathrm{n}$.

20 Zob. J. Jończyk, Prawo zabezpieczenia społecznego, Kraków 2006, s. 11-12, 21. Taki punkt widzenia podziela autor niniejszego opracowania i, jak się wydaje, na przykład D.E. Lach, Zasada równego dostępu do świadczeń opieki zdrowotnej, Warszawa 2011, s. 207-208, choć (w kontekście analizy ryzyka niezdrowia) odróżnia on ryzyko jako niebezpieczeństwo (możliwość wystąpienia zdarzenia losowego) „od ryzyka socjalnego drugiego stopnia jako pojęcia prawnego, precyzującego, czy dane zdarzenie losowe (jego skutki) objęte są systemową gwarancją". Por. też A. Napiórkowska, Ryzyko w ubezpieczeniu społecznym, „Państwo i Prawo” 2012, z. 12, s. 70-71, która na gruncie ubezpieczeń społecznych proponuje zastąpić termin „zdarzenie losowe” pojęciem „zdarzenie życiowe” ze względu na jego ścisły związek z życiem człowieka. 
To drugie, moim zdaniem właściwsze, stanowisko co do pojęcia ryzyka ubezpieczeniowego (w tym socjalnego) wpisuje się w konkurencyjną wobec teorii świadczenia pieniężnego (Geldleistungstheorie) teorię ponoszenia ryzyka/ciężaru niebezpieczeństwa (Gefahrtragungstheorie) przez ubezpieczyciela w postaci zapłaty określonej sumy pieniężnej w razie zajścia wypadku ubezpieczeniowego ${ }^{21}$. Zgodnie z tym poglądem „Świadczenie przez ubezpieczyciela ochrony ubezpieczeniowej ma dla ubezpieczającego (ubezpieczonego) wartość samą w sobie" i wiąże się między innymi z „korzyściami czysto psychicznymi (spokój, możność usunięcia na dalszy plan trosk dotyczących określonego wymiaru bezpieczeństwa majątkowego)"22. Stwierdzenia te korespondują z zapatrywaniem, że położenie akcentu na ryzyku (a nie na świadczeniach), czyli gwarancyjnej fazie ubezpieczenia, „uwalnia człowieka od obawy (strachu) przed skutkami socjalnego ryzyka i tworzy więcej przestrzeni dla aktywności zawodowej, gospodarczej, społecznej i politycznej, czyli mówiąc krótko — dla wolności"23. Ogólnie można więc stwierdzić, że w przyjętym rozumieniu ochrona ubezpieczeniowa sprowadza się do odczuwania komfortu psychicznego (poczucia bezpieczeństwa materialnego/ socjalnego) zapewnionego przez sam fakt ubezpieczenia, tym samym za świadczenie wzajemne z tytułu bezwarunkowo opłacanej składki uważa się przejęcie i ponoszenie ryzyka przez ubezpieczyciela, a nie ewentualne wypłacenie świadczenia ubezpieczeniowego ${ }^{24}$.

\section{RYZYKO SOCJALNE JAKO RYZYKO UBEZPIECZENIOWE}

Dalsze rozważania należy poświęcić problematyce kwalifikacji ryzyka socjalnego ${ }^{25}$ jako ryzyka ubezpieczeniowego. Nie powinno być bowiem wątpliwości, że ryzyko socjalne jest odmianą (typem) ryzyka ubezpieczeniowego znanego ogólnej teorii ubezpieczeń w tej ich części, która w Polsce nosi miano ubezpieczeń gospodarczych (majątkowych i osobowych). Prawo ubezpieczeń społecznych jak dotąd

21 Zob. M. Orlicki, [w:] System prawa prywatnego. Prawo zobowiazań - część szczegółowa, t. 8, red. J. Panowicz-Lipska, Warszawa 2011, s. 838-841 i podana tam literatura w przyp. 63-64; W. Warkałło, [w:] W. Warkałło, W. Marek, W. Mogilski, Prawo ubezpieczeniowe, Warszawa 1983, s. 254.

22 M. Orlicki, op. cit., s. 839.

23 J. Jończyk, op. cit., s. 21.

24 Szerzej zob. K. Antonów, Prawo ubezpieczeń społecznych a prawo ubezpieczeń gospodarczych (osobowych), „Opolskie Studia Administracyjno-Prawne” 16, 2018, nr 3, s. 51-54 i podaną tam literaturę.

25 W Polsce pojęcie to na szeroką skalę do obrotu prawnego wprowadził J. Jończyk, op. cit., s. 12 n. Wcześniej tym terminem posłużył się C. Jackowiak, [w:] W. Jaśkiewicz, C. Jackowiak, W. Piotrowski, Prawo pracy w zarysie, Warszawa 1985, s. 454. Natomiast w literaturze obcojęzycznej pojęciem social risks posługuje się na przykład D. Pieters, Social Security: An Introduction to the Basic Principles, Alphen aan den Rijn 2006, s. 31 n. 
nie stworzyło własnej koncepcji ryzyka socjalnego, odwołując się w tym zakresie do dorobku przedstawicieli nauki prawa ubezpieczeń gospodarczych i dokonując oczywiście niezbędnych modyfikacji niektórych elementów konstrukcyjnych ryzyka ubezpieczeniowego w związku z socjalnym przeznaczeniem ubezpieczeń społecznych. Do pewnego stopnia taki stan rzeczy jest usprawiedliwiony tym, że pojęcia ryzyka socjalnego w jego zasadniczych zrębach nie można odseparować od pojęcia ryzyka ubezpieczeniowego, które jest wobec niego pierwotne (to jest wcześniejsze historycznie) i nadrzędne w tym sensie, że w strukturze ryzyka socjalnego nie można zrezygnować $\mathrm{z}$ wielu cech identyfikujących ryzyko ubezpieczeniowe jako ryzyko we właściwym tego słowa znaczeniu, to znaczy będącego przyczyną ustanawiania ochrony ubezpieczeniowej ze względu na zagrożenie zajścia wypadku (zdarzenia) ubezpieczeniowego o między innymi niekorzystnym, niepewnym, przyszłym i losowym charakterze ${ }^{26}$. Ochrona ta bowiem niezależnie od rodzaju ubezpieczeń (społecznych czy gospodarczych — osobowych) obejmuje jednostki z mocy prawa lub na zasadzie dobrowolności w związku $\mathrm{z}$ istnieniem potencjalnego niebezpieczeństwa ziszczenia się określonych sytuacji życiowych przynoszących stratę (ujemną konsekwencję, „,szkodę”) w sferze życia, zdrowia i zdolności do pracy ${ }^{27}$. Dlatego też ryzyko ubezpieczeniowe (w tym socjalne) wyznacza przedmiot ubezpieczenia (katalog chronionych ryzyk) oraz instrumenty prawne służące łagodzeniu skutków ich zajścia (katalog świadczeń ubezpieczeniowych) ${ }^{28}$.

Zważywszy jednak na inne cele ubezpieczeń (społecznych i gospodarczych) ${ }^{29}$ oraz istotne rozbieżności w zakresie szczegółowych rozwiązań prawnych w tych dziedzinach ${ }^{30}$, uprawnione wydaje się wprowadzenie terminologicznego dookreślenia ryzyka ubezpieczeniowego występującego na gruncie prawa ubezpieczeń społecznych (czy szerzej prawa zabezpieczenia społecznego) i prawa ubezpieczeń gospodarczych, to jest odpowiednio pod postacią pojęcia „ryzyko socjal-

${ }^{26}$ Do tego dodać można jeszcze takie cechy, jak: nadzwyczajność, masowość, statystyczną prawidłowość czy niezależność od woli jednostki. Zob. J. Łazowski, op. cit., s. 8 n.; W. Warkałło, [w:] Ubezpieczenia ..., s. 49 n.; W. Warkałło, [w:] Prawo..., s. 176 n.; J. Dubiński, [w:] Ubezpieczenia życiowe, red. O. Doan, Warszawa 1996, s. 34-36; E. Kowalewski, [w:] Ubezpieczenia gospodarcze ..., s. 50-51; T. Michalski, op. cit., s. 18. Por. też cztery elementy ryzyka ubezpieczeniowego w ujęciu E.J. Vaughana (E.J. Vaughan, T. Vaughan, op. cit., s. 42-43), to jest, nieco upraszczając, masowość, mierzalność, przypadkowość oraz niekatastrofalny charakter.

27 W obszarze ubezpieczeń społecznych i gospodarczych (osobowych) zajście ryzyka powoduje zatem jakąś biologiczną dysfunkcję organizmu człowieka, co sprawia, że tego typu ryzyka noszą miano ryzyk biotycznych. Zob. I. Jędrasik-Jankowska, op. cit., s. 127, która zawarła objaśnienia na ten temat, odwołując się między innymi do opracowania W. Warkałły, Prawo i ryzyko. Prewencja, represja i kompensacja w polityce przeciwszkodowej, Warszawa 1949, s. 33.

28 Zob. K. Antonów, Prawo do emerytury, Kraków 2003, s. 22-23.

29 Zob. T. Zieliński, op. cit., s. 26-27.

$30 \mathrm{~W}$ skondensowanej formie zob. K. Antonów, [w:] Prawo pracy i ubezpieczeń społecznych, red. K.W. Baran, Warszawa 2019, s. 736, schemat 22. Natomiast szerzej o tych różnicach zob. idem, Prawo ubezpieczeń..., s. 54 n. 
ne” i „ryzyko prywatne” lub „ryzyko komercyjne”31. Kryterium podziału na te dwie odmiany ryzyka ubezpieczeniowego opiera się przede wszystkim na różnicach w stopniu uspołecznienia obu ubezpieczeń w znaczeniu realizacji ochrony ubezpieczeniowej nie tylko w interesie osoby ubezpieczonej i ewentualnie jej bliskich (jak w przypadku ubezpieczeń gospodarczych), lecz również na rzecz całej wspólnoty ryzyka czy nawet ogółu społeczeństwa (jak w ubezpieczeniach społecznych), co można osiągnąć wyłącznie za pomocą przymusu ubezpieczenia i różnego rodzaju mechanizmów solidarnościowych ${ }^{32}$, a nie w ramach, co do zasady, dobrowolnej przezorności jednostek oraz równowartości składki do świadczenia ${ }^{33}$ i zarobkowej (to jest w celu osiągania zysku) działalności zakładów ubezpieczeń. Natomiast w obu ubezpieczeniach taki sam jest powód ustanowienia ochrony ubezpieczeniowej, to jest zagwarantowanie (przyrzeczenie) świadczenia na wypadek poniesienia straty w dobrach niemajątkowych (osobistych) ubezpieczonego w związku z wystąpieniem ryzyka ubezpieczeniowego (socjalnego lub prywatnego/komercyjnego) oraz spełnieniem ustawowych lub sformułowanych w ogólnych warunkach ubezpieczenia przesłanek przyznania świadczenia.

\section{RYZYKO SOCJALNE JAKO NIEBEZPIECZEŃSTWO ZAJŚCIA ZDARZENIA UBEZPIECZENIOWEGO}

Przedstawienie teorii ryzyka oraz ukazanie ryzyka socjalnego jako szczególnej postaci ryzyka ubezpieczeniowego uzasadnia przejście do rozważań o koncepcji ryzyka socjalnego w polskim prawie ubezpieczeń społecznych. Zgodnie z wcześniejszymi stwierdzeniami stoję na stanowisku, że ryzyko socjalne należy rozpatrywać w kategoriach niebezpieczeństwa, czyli większą wagę przykładać do przyczyn powstania różnego rodzaju zagrożeń i sposobów ich uniknięcia lub ograniczenia ujemnych następstw niż do skutków, jakie one wywołują w postaci generowania potrzeb materialnych zaspokajanych świadczeniami ubezpieczeniowymi. Innymi słowy punkt ciężkości w analizie ryzyka socjalnego należy przesunąć z obszaru realizacji skutków ryzyka (zaspokajania potrzeb) w stronę ubezpieczenia ryzyka jako gwarancji złagodzenia jego negatywnych konsekwen-

31 Propozycję takiego podziału ryzyka ubezpieczeniowego zawarłem już wcześniej w opracowaniu Prawo ubezpieczeń..., s. 51.

32 Mam tu na myśli stosowanie reguł tak zwanego wyrównania socjalnego polegających na korygowaniu nierówności w zakresie indywidualnego przyczyniania się do ponoszenia kosztu ubezpieczenia, jak na przykład formuł od bogatszych do biedniejszych czy od mężczyzn do kobiet — zob. M. Żukowski, Wielostopniowe systemy zabezpieczenia emerytalnego w Unii Europejskiej i w Polsce. Między państwem a rynkiem, Poznań 1997, s. 43-44.

$33 \mathrm{~W}$ znaczeniu uzależnienia wysokości składki od indywidualnej oceny stopnia zajścia ryzyka ubezpieczeniowego (na przykład wieku i stanu zdrowia ubezpieczonego w ubezpieczeniu na życie czy bezszkodowości w ubezpieczeniu OC kierowców pojazdów mechanicznych). 
$\mathrm{cji}^{34}$, wedle rozumowania, że to fakt istnienia ryzyk ubezpieczeniowych przesądza o występowaniu zdarzeń, a nie odwrotnie (jak w koncepcji zdarzeń losowych), to jest $\mathrm{z}$ występowania określonych zdarzeń wnosi się o istnieniu ryzyka ${ }^{35}$.

$\mathrm{W}$ takim ujęciu na pierwszy plan wysuwa się zagadnienie racjonalizacji kosztu ubezpieczenia ${ }^{36}$, który nie powinien być swoistym zakładnikiem potrzeb, z natury rzeczy nieograniczonych i dla których trudno znaleźć jakąś obiektywną miarę ich zaspokojenia. Konstrukcja prawna oparta na ubezpieczeniu ryzyka wraz z działaniami zapobiegającymi jego wystąpieniu (prewencja ubezpieczeniowa $)^{37}$ i stosowaniem sankcji w razie zawinionego postępowania ubezpieczonego (złamanie wymogu lojalności) $)^{38}$ - zwiększa prawdopodobieństwo podwyższenia jakości ochrony ubezpieczeniowej (dostępności i wymiaru świadczeń), gdyż $\mathrm{w}$ przeciwieństwie do teorii zaspokajania potrzeb za pomocą świadczeń pieniężnych w większym stopniu uwzględnia ubezpieczeniowy charakter instytucji ubezpieczeń społecznych, biorąc pod uwagę ich aktuarialne podstawy mające znaczenie dla prawidłowego ukształtowania reguł solidarnościowych i sprawiedliwego rozdziału świadczeń. Mam tu w szczególności na myśli przeciwdziałanie arbitralnemu wyłączaniu niektórych kręgów społecznych ze wspólnoty ryzyka lub faworyzowanie jakichś grup zawodowych wewnątrz tej zbiorowości, a także nadmierne (ponad usprawiedliwione socjalnym przeznaczeniem ubezpieczeń społecznych) odstępowanie od zasady odpłatności w relacji składka - świadczenie na rzecz mechanizmów wyrównawczych zanadto ograniczających znaczenie stażu ubezpieczeniowego i własnego wkładu przy ustalaniu prawa do świadczenia i jego wysokości. Nie można też pominąć wpływu tak rozumianego ubezpieczenia na umacnianie więzi społecznych między ludźmi znajdującymi się w sytuacji zagrożenia i podejmującymi wspólny wysiłek odparcia grożących niebezpieczeństw.

Kierując się tym zapatrywaniem, ryzyko socjalne należy określić jako niebezpieczeństwo zajścia zdarzenia ubezpieczeniowego. Ryzyka jako byty niezależne od zdarzeń istnieją obiektywnie i mają abstrakcyjny charakter. Stanowią potencjalne zagrożenie dóbr osobistych (niemajątkowych) osób podlegających ubezpieczeniom społecznym, których realizacja sprowadza się do zaprzestania zarobkowania z powodu wystąpienia trwałej lub okresowej przeszkody w samodzielnym uzyskiwaniu środków utrzymania. Zdarzenia ubezpieczeniowe są zatem konsekwencją istnienia ryzyk z zastrzeżeniem, że nie każde ryzyko (prawdopo-

34 Zob. J. Jończyk, op. cit., s. 11-12.

35 W. Warkałło, [w:] Ubezpieczenia ..., s. 38.

36 Tak, żeby ciężar finansowania świadczeń nie stanowił konsekwencji priorytetu potrzeb J. Jończyk, op. cit., s. 11.

37 W sferze ubezpieczeń społecznych z prewencją ubezpieczeniową (rentową i wypadkową) mamy do czynienia w ubezpieczeniach rentowych (art. 69 ustawy z dnia 13 października 1998 roku o systemie ubezpieczeń społecznych, tekst jedn. Dz.U. z 2020 r. poz. 266) i ubezpieczeniu wypadkowym (rozdział 5 ustawy z dnia 30 października 2002 roku o ubezpieczeniu społecznym z tytułu wypadków przy pracy i chorób zawodowych, tekst jedn. Dz.U. z 2019 r. poz. 1205).

${ }^{38} \mathrm{Na}$ ten temat zob. rozległe wywody D.E. Lacha - idem, op. cit., s. $218 \mathrm{n}$. 
dobne niebezpieczeństwo) się zmaterializuje (przeistoczy) w zdarzenie, gdyż nie zawsze dojdzie do ziszczenia się określonego stanu faktycznego, z którym ustawa wiąże spełnienie, zazwyczaj w powiązaniu z innymi (prawnymi) przesłankami, warunku nabycia prawa do świadczenia. $Z$ przyznaniem i pobieraniem konkretnego świadczenia mamy zatem do czynienia dopiero gdy ryzyko przybierze charakter normatywny, to znaczy, z jego wystąpieniem związany będzie obowiązek prawny ustalenia prawa do świadczenia, jeżeli wystąpią faktyczne i prawne skutki zdarzenia ubezpieczeniowego (zob. schemat 1$)^{39}$.

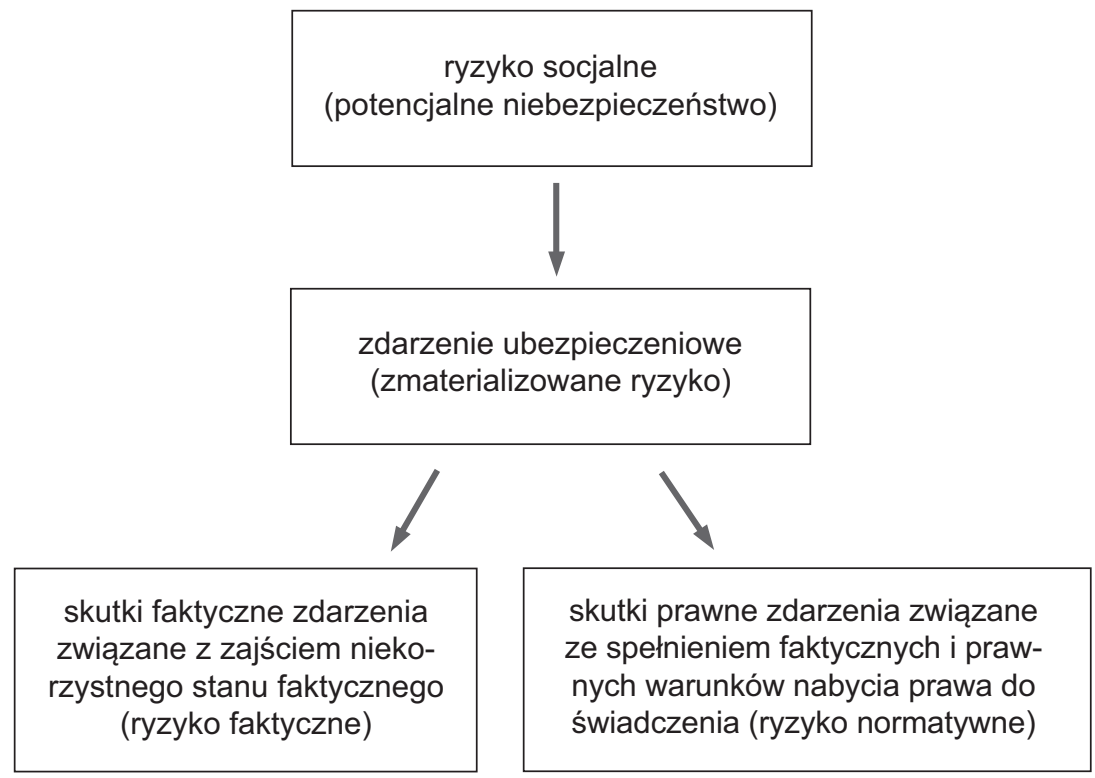

Schemat 1. Ryzyko socjalne w ujęciu dynamicznym

Źródło: opracowanie własne.

W sensie prawnym (zob. schemat 2) ekspektatywa ubezpieczonego (narastająca w fazie gwarancyjnej) do potencjalnego świadczenia pieniężnego przeobraża się (w chwili zajścia ryzyka i spełnienia ustawowych warunków) w konkretne prawo podmiotowe o charakterze majątkowym, a zdarzenie ubezpieczeniowe staje się zdarzeniem prawnym ${ }^{40}$. W kategoriach zobowiązaniowych po stronie ubezpieczonego powstaje więc wierzytelność „w postaci uprawnienia (roszczenia) do uzyskania świadczenia [...], czyli dobra (korzyści) wyrażającego się w przyznaniu określonej sumy pieniężnej”41.

$39 \mathrm{~W}$ zakresie terminologii związanej z pojęciem ryzyka nawiązuję do pracy W. Sanetry (Ryzyko osobowe zakładu pracy, Warszawa 1971), w której autor wyróżnił ryzyko faktyczne, prawne i normatywne.

40 Por. W. Warkałło, [w:] Ubezpieczenia ..., s. 40 n.

41 K. Antonów, Sprawy z zakresu ubezpieczeń spolecznych. Pojęcie oraz właściwości postępowań przedsądowych i ochrony cywilnosądowej, Warszawa 2011, s. 101. 


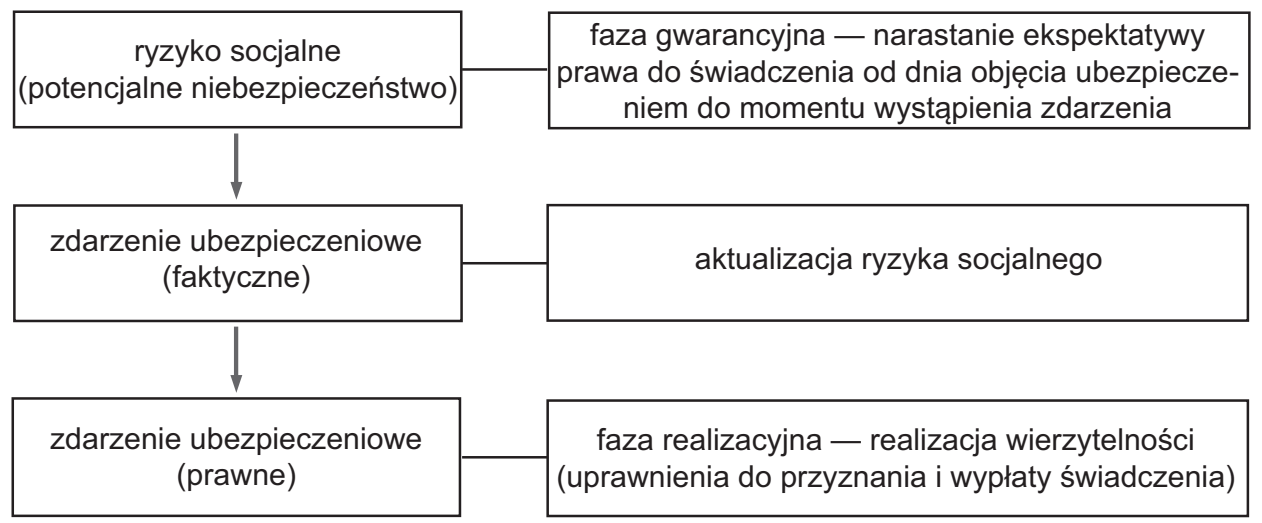

Schemat 2. Ryzyko socjalne w ujęciu prawnym

Źródło: opracowanie własne.

Po tych wyjaśnieniach można przejść do zaprezentowania ryzyk socjalnych ${ }^{42}$ w obszarze prawa ubezpieczeń społecznych w relacji do zdarzeń ubezpieczeniowych i skutków w sferze realizacji ochrony ubezpieczeniowej (zob. tabela 1).

Tabela 1. Rodzaje ryzyk socjalnych i zdarzeń ubezpieczeniowych w prawie ubezpieczeń społecznych wraz z przysługującą ochroną ubezpieczeniową

\begin{tabular}{|l|l|l|}
\hline \multicolumn{1}{|c|}{ Ryzyko socjalne } & \multicolumn{1}{|c|}{$\begin{array}{c}\text { Podstawowe zdarzenia } \\
\text { ubezpieczeniowe }\end{array}$} & \multicolumn{1}{|c|}{$\begin{array}{c}\text { Świadczenie jako forma } \\
\text { realizacji ochrony } \\
\text { ubezpieczeniowej }\end{array}$} \\
\hline dożycie wieku emerytalnego & $\begin{array}{l}\text { zaprzestanie pracy po osiągnię- } \\
\text { ciu wieku emerytalnego }\end{array}$ & emerytury \\
\hline $\begin{array}{l}\text { całkowita lub częściowa nie- } \\
\text { zdolność do pracy }\end{array}$ & $\begin{array}{l}\text { choroba z tak zwanego ogól- } \\
\text { nego stanu zdrowia, wypadek } \\
\text { w drodze do pracy lub z pracy, } \\
\text { wypadek w życiu prywatnym }\end{array}$ & $\begin{array}{l}\text { pracyta z tytułu niezdolności do } \\
\text { pracy }\end{array}$ \\
\hline utrata żywiciela & $\begin{array}{l}\text { śmierć ubezpieczonego, eme- } \\
\text { ryta lub rencisty }\end{array}$ & $\begin{array}{l}\text { renta rodzinna i zasiłek pogrze- } \\
\text { bowy }\end{array}$ \\
\hline $\begin{array}{l}\text { czasowa niezdolność lub nie- } \\
\text { możność świadczenia pracy }\end{array}$ & $\begin{array}{l}\text { choroba ubezpieczonego lub } \\
\text { członka rodziny, urodzenie } \\
\text { dziecka i opieka nad nim } \\
\text { w 1. roku życia }\end{array}$ & $\begin{array}{l}\text { zasiłki (chorobowy, macie- } \\
\text { rzyński i opiekuńczy) oraz } \\
\text { świadczenie rehabilitacyjne }\end{array}$ \\
\hline $\begin{array}{l}\text { wypadek przy pracy, choroba } \\
\text { zawodowa }\end{array}$ & $\begin{array}{l}\text { uraz albo śmierć ubezpieczo- } \\
\text { nego lub rencisty }\end{array}$ & $\begin{array}{l}\text { zasiłki, renty i jednorazowe } \\
\text { odszkodowanie }\end{array}$ \\
\hline
\end{tabular}

Źródło: opracowanie własne.

42 Katalog ryzyk i zdarzeń ubezpieczeniowych wymienionych tabeli 1 przy uwzględnieniu opracowań J. Jończyka — idem, op. cit., s. 13; oraz I. Jędrasik-Jankowskiej — eadem, op. cit., s. 130. 
Konstrukcja przedstawionych ryzyk socjalnych zakłada, że do ich podstawowych właściwości należy zaliczyć (jak to ująłem we wcześniejszym opracowaniu ${ }^{43}$ ) następujące cechy: niepewność, niekorzystność, niezależność od woli człowieka, losowość, przyszłość, prawne wyodrębnienie i aktuarialną obliczalność. W szczególności należy zwrócić uwagę na dwa pierwsze elementy ryzyka socjalnego na gruncie prawa ubezpieczeń społecznych. Wprawdzie w niniejszym opracowaniu była już mowa o relacji ryzyka do niepewności (zob. pkt 1), ale rozważania na ten temat nie dotyczyły ryzyk socjalnych, które — ze względu na swoją społeczną naturę - wymagają odrębnej analizy w tym kontekście. Trzeba bowiem podkreślić, że niepewność jako cecha ryzyka może polegać na: niepewności co do nastąpienia zdarzenia (incertitudo an), niepewności co do skutków zdarzenia (incertitudo effectus) czy też niepewności co do daty nastąpienia zdarzenia (incertitudo quando $)^{44}$.

Przenosząc ten podział na obszar ryzyk socjalnych, trzeba odnotować, że zasadniczo odznaczają się one niepewnością w pierwszym znaczeniu tego pojęcia, to jest niepewnością rozumianą jako możliwość nastąpienia zdarzenia, z wyłączeniem jednak pewności, że tak się stanie. $Z$ innym rodzajem niepewności mamy jednak do czynienia w razie zajścia zdarzenia śmierci. Wiadomo bowiem, że śmierć jest zdarzeniem pewnym, nie jest natomiast możliwe indywidualne ustalenie, kiedy ona nastąpi, dlatego w tym przypadku chodzi o niepewność typu incertitudo quando. Przy czym należy zastrzec, że prawu ubezpieczeń społecznych nie jest znane ubezpieczenie w formie ubezpieczenia na życie, w którym śmierć ubezpieczonego - wyjąwszy samobójstwo w dwóch pierwszych latach ubezpieczenia (art. 833 k.c. $)^{45}$ - niemal zawsze wiąże się z wypłatą świadczenia. W obszarze ubezpieczeń społecznych śmierć ubezpieczonego jest jedną z przesłanek nabycia prawa do renty rodzinnej (,zwykłej” i wypadkowej), jednorazowego odszkodowania lub zasiłku pogrzebowego. W odniesieniu do wymienionych świadczeń (może z wyjątkiem zasiłku pogrzebowego) ${ }^{46}$ — inaczej niż w ubezpieczeniu na życie istotą ubezpieczenia z tytułu utraty żywiciela albo śmierci związanej z wypadkiem przy pracy lub chorobą zawodową nie jest życie ubezpieczonego, lecz brak lub zmniejszenie środków utrzymania po stronie członków rodziny zmarłego. Przyznanie świadczenia (zwłaszcza renty rodzinnej) nie jest także — jak ma to miejsce w przypadku świadczenia $\mathrm{z}$ tytułu śmierci ubezpieczonego w ubezpieczeniu na życie - uzależnione wyłącznie od nastąpienia zdarzenia śmierci. W związku

${ }^{43}$ Zob. K. Antonów, [w:] Prawo pracy..., s. 739.

44 Zob. E. Kowalewski, [w:] Ubezpieczenia gospodarcze..., s. 51.

45 Inne wyłączenia to na przykład śmierć w wyniku działań wojennych, umyślnego przestępstwa czy wypadku komunikacyjnego, gdy ubezpieczony prowadził pojazd w stanie nietrzeźwości.

46 Konstrukcja prawna zasiłku pogrzebowego wydaje się najbliższa modelowi ubezpieczenia na życie, gdyż śmierć stanowi tu (nie licząc obowiązku pokrycia kosztów pogrzebu) praktycznie jedyną przesłankę, z tytułu której członkowi rodziny zmarłego przysługuje to świadczenie. 
z tym, zwłaszcza że śmierć nie prowadzi automatycznie do nabycia prawa do renty rodzinnej ${ }^{47}$, kwestia daty nastąpienia tego zdarzenia odgrywa tu mniejszą rolę.

Analizując niepewność jako cechę ryzyka socjalnego, należy jeszcze zwrócić uwagę, że wśród zdarzeń ubezpieczeniowych występują również zdarzenia niemające takiego atrybutu. Mam tu na myśli urodzenie dziecka, ponieważ powszechnie dostępna wiedza na temat zasad reprodukcji (wytwarzania potomstwa przez organizmy żywe, w tym ludzi) nie pozwala przyjąć, że zajście w ciążę jest dziełem przypadku, nawet jeżeli ciąża jest niezaplanowana. W związku z tym urodzenie dziecka należy zakwalifikować do zdarzeń zrównanych ze zdarzeniami ubezpieczeniowymi ${ }^{48}$, ale $\mathrm{w}$ istocie niespełniających właściwości ryzyka ubezpieczeniowego (socjalnego). Niezależnie od tego negatywne skutki urodzenia dziecka związane z czasową niemożnością zarobkowania wymagają udzielenia ochrony prawnej, która - mając na względzie zarówno szczególną sytuację kobiet w okresie połogu (regeneracja sił po porodzie), jak i konieczność sprawowania opieki na niemowlęciem — realizowana jest również w sferze ubezpieczeń społecznych (zasiłek macierzyński).

Należy też zaznaczyć, że przejawy ryzyk socjalnych w postaci zdarzeń ubezpieczeniowych, aby mogły być zaliczone do ryzyk we właściwym tego słowa rozumieniu (tak zwanych ryzyk czystych), muszą mieć charakter niekorzystny. W tym kontekście odrzucam pogląd o możliwości zaliczenia do zdarzeń ubezpieczeniowych zdarzeń pomyślnych (szczęśliwych), choćby (jak dożycie określonego wieku) stwarzały one nowe zapotrzebowanie materialne ${ }^{49}$. Uważam zatem, że również ryzyko dożycia wieku emerytalnego charakteryzuje się niekorzystnością, z zastrzeżeniem jednak że nie chodzi tu o niekorzystność uwidaczniającą się w samym osiągnięciu tego wieku, lecz negatywnych skutkach z tym związanych. Przede wszystkim trzeba zauważyć, że wraz z osiągnięciem powszechnego wieku emerytalnego (60/65 lat) kończy się szczególna — trwająca wcześniej 4 lata — ochrona przed wypowiedzeniem stosunku pracy (art. 39 k.p.). W ten sposób ustaje formalne ograniczenie $\mathrm{w}$ dziedzinie rozwiązania umowy o pracę przez pracodawcę ${ }^{50}$, a niebezpieczeństwo utraty pracy i płacy staje się realne. Powstają więc warunki do zajścia zdarzenia ubezpieczeniowego w postaci zaprzestania zatrudnienia, z którym - co oczywiście nie dotyczy zatrudnienia pozapracowniczego — ustawa wiąże uruchomienie prawa do pobierania emerytury (art. 103a ustawy z dnia 17 grudnia 1998 roku o emeryturach i rentach z Funduszu Ubezpieczeń

47 Ponadto gdy renta rodzinna została nabyta, osoby uprawnione do niej nie zawsze będą ją pobierały czy to ze względu na jej niższą wysokość w stosunku do innego równolegle przysługującego świadczenia, czy też z uwagi na osiąganie przychodów ponad dopuszczalny limit umożliwiający łączenie wypłaty tego świadczenia z zarobkami z pracy lub działalności.

48 Podobnie T. Zieliński, op. cit., s. 182.

49 Zob. J. Łazowski, op. cit., s. 3-4.

${ }^{50} \mathrm{Z}$ zastrzeżeniem, że wypowiedzenie stosunku pracy nie może przybrać dyskryminacyjnego charakteru — zob. K. Antonów, [w:] Prawo pracy..., s. 812. 
Społecznych ${ }^{51}$ ). Negatywne skutki dożycia wieku emerytalnego ujawniają się także na płaszczyźnie pozaprawnej, a mianowicie w dziedzinie ekonomicznej. Nie ulega bowiem wątpliwości, że standardowa wysokość świadczenia emerytalnego jest zazwyczaj niższa od ostatniego lub średniego przychodu z pracy lub działalności. Wraz zatem z przejściem na emeryturę następuje spadek dotychczasowego poziomu życia, czego najlepszą ilustracją jest wskaźnik stopy zastąpienia (replacement rate), który w Polsce w 2018 roku wyniósł 56,4\%. Jakkolwiek generalnie niższa wysokość świadczenia ubezpieczeniowego od wcześniej uzyskiwanego przychodu jest zjawiskiem zrozumiałym i wynika z istoty instytucji ubezpieczenia służącego łagodzeniu, a nie wyrównywaniu skutków zajścia ryzyk życiowych ${ }^{52}$, zarazem jest to wyraźnie niekorzystne, co wzmacnia tezę o niekorzystności skutków ryzyka emerytalnego.

\section{PODSUMOWANIE}

Krótko podsumowując niniejsze rozważania, należy stwierdzić, że tworząc zarys koncepcji ryzyka socjalnego w polskim prawie ubezpieczeń społecznych, nie można nie uwzględnić teorii ryzyka charakterystycznej dla amerykańskiej myśli ekonomicznej w zakresie ujmowania tego pojęcia w kategoriach niebezpieczeństwa postrzeganego jako przyczyna realnych zdarzeń. Konsekwencją przyjęcia takiej metody analizy ryzyka socjalnego jest wyeksponowanie gwarancyjnej fazy ubezpieczeń społecznych w celu podkreślenia, że — nie ignorując znaczenia fazy realizacyjnej — o jakości świadczenia (jako tylko potencjalnej „korzyści”) decyduje racjonalne ułożenie mechanizmów zabezpieczających członków wspólnoty ryzyka przed nastąpieniem strat w dobrach osobistych (niemajątkowych). Kluczowe jest tu zatem wytworzenie rzeczywistego przekonania (a nie złudzenia), że ochrona ubezpieczeniowa nie wiąże się wyłącznie z otrzymaniem świadczenia, lecz nade wszystko polega na odczuwaniu spokoju psychicznego i uwolnieniu od lęku o brak bezpieczeństwa socjalnego (materialnego). Mając to na uwadze, ryzyko socjalne należy rozpatrywać nie od strony zaspokojenia potrzeb, jakie ono niesie, gdy się ziści (teoria świadczenia pieniężnego), lecz w kontekście świadczenia ubezpieczeniowej gwarancji „na wypadek” zajścia określonych zdarzeń (teoria ponoszenia ryzyka).

51 Tekst jedn. Dz.U. z 2020 r. poz. 53 ze zm.

52 Innymi słowy, jak słusznie przed laty stwierdził J. Łazowski (op. cit., s. 8), celem ubezpieczenia nie może być wzbogacenie. 


\section{THE CONCEPTION OF SOCIAL RISK IN POLISH SOCIAL INSURANCE LAW}

Summary

The outline of the concept of social risk in Polish social insurance law has been created using the American (economic) approach toward insurance risk theory that perceives this term in a category of a risk, regarded as a cause of real incidents. As a consequence, the idea of insurance protection is reduced to possessing mental comfort (a feeling of material safety) ensured by the sheer fact of being insured, therefore assuming and bearing risk by the social insurance authority, and not possible payment of benefits, is considered a mutual contribution for unconditionally paid social insurance premiums. Having the aforementioned in mind, the social risk should be examined not in relation to fulfilment of needs which takes place when the risk is materialized (the pecuniary contribution theory), but in a context of providing an insurance guarantee "in case" particular events occur (risk bearing theory).

Keywords: social risk, insurance risk, insurance event, insurance coverage, social insurance law

\section{BIBIOGRAFIA}

Antonów K., [w:] Prawo pracy i ubezpieczeń społecznych, red. K.W. Baran, Warszawa 2019.

Antonów K., Prawo do emerytury, Kraków 2003.

Antonów K., Prawo ubezpieczeń społecznych a prawo ubezpieczeń gospodarczych (osobowych), „Opolskie Studia Administracyjno-Prawne” 16, 2018, nr 3.

Antonów K., Sprawy z zakresu ubezpieczeń społecznych. Pojęcie oraz właściwości postępowań przedsadowych i ochrony cywilnosadowej, Warszawa 2011.

Dubiński J., [w:] Ubezpieczenia życiowe, red. O. Doan, Warszawa 1996.

Dzienisiuk D., Prawo pracy a prawo ubezpieczeń społecznych, Warszawa 2016.

Jackowiak C., [w:] W. Jaśkiewicz, C. Jackowiak, W. Piotrowski, Prawo pracy w zarysie, Warszawa 1985.

Jędrasik-Jankowska I., Pojęcia i konstrukcje prawne ubezpieczenia społecznego, Warszawa 2018.

Jończyk J., Prawo zabezpieczenia społecznego, Kraków 2006.

Knight F.H., Risk, Uncertainty And Profit, Boston- New York 1921.

Kowalewski E., [w:] Ubezpieczenia w gospodarce rynkowej, cz. 2, red. A. Wąsiewicz, Bydgoszcz 1994.

Kowalewski E., [w:] Ubezpieczenia gospodarcze, red. T. Sangowski, Warszawa 2000.

Lach D.E., Zasada równego dostępu do świadczeń opieki zdrowotnej, Warszawa 2011.

Łazowski J., Wstęp do nauki o ubezpieczeniach, Warszawa 1934.

Michalski T., [w:] Podstawy ubezpieczeń. Mechanizmy i funkcje, t. 1, red. J. Monkiewicz, Warszawa 2000.

Napiórkowska A., Ryzyko w ubezpieczeniu społecznym, „Państwo i Prawo” 2012, z. 12.

Orlicki M., [w:] System prawa prywatnego, t. 8. Prawo zobowiazań - część szczegółowa, red. J. Panowicz-Lipska, Warszawa 2011.

Pieters D., Social Security: An Introduction to the Basic Principles, Alphen aan den Rijn 2006.

Sanetra W., Ryzyko osobowe zaktadu pracy, Warszawa 1971.

Szubert W., Ubezpieczenie spoleczne. Zarys systemu, Warszawa 1987.

Vaughan E.J., Vaughan T., Fundamentals of Risk and Insurance, New York 2008.

Warkałło W., [w:] Ubezpieczenia majątkowe. Ochrona ubezpieczeniowa mienia społecznego, red. W. Warkałło, Warszawa 1971. 
Warkałło W., [w:] W. Warkałło, W. Marek, W. Mogilski, Prawo ubezpieczeniowe, Warszawa 1983.

Warkałło W., Prawo i ryzyko. Prewencja, represja i kompensacja w polityce przeciwszkodowej, Warszawa 1949.

Willett A.H., The Economic Theory of Risk and Insurance, New York 1901.

Wypych-Żywicka A., Renta rodzinna z Funduszu Ubezpieczeń Społecznych. Zagadnienia materialnoprawne, Gdańsk 2006.

Zieliński T., Ubezpieczenia społeczne pracowników. Zarys systemu prawnego — część ogólna, Warszawa-Kraków 1994.

Żukowski M., Wielostopniowe systemy zabezpieczenia emerytalnego w Unii Europejskiej $i$ w Polsce. Między państwem a rynkiem, Poznań 1997. 